\title{
Analysis of Relationship among Production, Supply-marketing and Mutual Fund Cooperatives: A Case Study of China
}

\author{
Guo Hua ${ }^{1, a}$, Zhang $\mathrm{Yu}^{2, \mathrm{~b}}$, Li Houjian ${ }^{*}, \mathrm{c}$ \\ ${ }^{1}$ Sichuan Agricultural University, No.112 Huimin Road, Wenjiang District, Chengdu, Sichuan, China, \\ 611130 \\ ${ }^{2}$ Sichuan Agricultural University, No.112 Huimin Road, Wenjiang District, Chengdu, Sichuan, China, \\ 611130 \\ * Sichuan Agricultural University, No.112 Huimin Road, Wenjiang District, Chengdu, Sichuan, China, \\ 611130 \\ a44528960@qq.com, b1138394228@qq.com, c107658474@qq.com
}

Keywords: production credit; supply-marketing; cooperatives; relationship

\begin{abstract}
Since the unbalance of the supply and demand of the rural finance in China's rural areas, the pilot cooperative of mutual fund were put forward. Sichuan Province, which located in the southwest China, is now the frontier of the rural revolution, and keep on exploring in practice, and gradually worked out a unique and outstanding path way according to the actual situation. Different from the model of the separated cooperative analyze, production, supply-marketing, and credit cooperation, or combining two of them, the innovation of the new cooperatives in Sichuan Province combines the three types of cooperation was founded. We use "Canonical correlation analysis"

(CCA) to analyze the interaction of each two of the three types of cooperation respectively and discuss the influencing factors of joining cooperatives, put forward relevant policy suggestions.
\end{abstract}

\section{Introduction}

In China, one of the key reforms nowadays in rural areas is refer to the cooperative economy. In 2015, central document pointed out: "to promote the reform of the rural financial system, deepening rural financial reform and innovation, and actively explore effective ways to develop new rural cooperative finance, and steadily carry out the internal mutual funds cooperatives pilot". Sichuan Province is an important reform pilot areas. As the pilot work steadily, the pilot has exposed some problems, also summed up some experiences. In Sichuan Province, mutual fund cooperatives are not an independent organization, but a part of production cooperative, its existence and development depend on the production cooperatives, it was designed for helping the members of production cooperatives, its services throughout the prenatal 、in production and postnatal, in this mode, the mutual fund cooperatives not only plays a role in financing, production cooperation, supply and marketing cooperation, credit cooperative are effectively combined together. The current China's rural financial reform has entered a crucial period, it is very important to deal with the problems in the development, to explore the development of mutual funds cooperatives, which are based on professional production cooperatives, not only is an effective means to solve the problem of the cooperative development fund, but also an effective form and important way to explore the development of Inclusive Finance.

\section{Literature review}

Zhang (1998) demonstrates agricultural production cooperation theory is complex, the practice is rich in developing countries, and production cooperatives should be based on the enthusiasm of farmers in production and management. Jia (2012) supports making the specific policies for specific the environment. Deepening rural reform and agricultural development on the basis of theoretical innovation should be continued. Yu (2014) Regulating the history of Japanese rural cooperative 
organization, we can found that agricultural cooperation organization is important to small agricultural management.

Yang (2013) demonstrates that cooperative organization and guarantee institution play an important role in agricultural supply chain system. Lu (2004) proposes that establish rural modern supply and marketing cooperative network. Lu (1986) points out the development the new economic union in rural areas of supply and marketing cooperation. Wu (2003) states that develope rural supply and marketing cooperative can promote rural economic development. Ma (2011) points out that the rural supply and marketing cooperative plays an important role in the development of rural economy, it sets up the logistics bridge for economic development in urban and rural areas, makes a big difference for the prosperity of the rural economy, ensuring the supply of urban and rural materials, promoting price stability in urban and rural areas.

In China, the current credit cooperative institutions in rural areas, mainly in the Rural credit cooperatives and agricultural Bank of China, Zheng (2013) believes that credit cooperation and production cooperation are coordinated development, mutual funds cooperatives are considered to be a major form that carry out cooperation in rural areas under the new situation. Cui (2009) states that mutual funds cooperatives can achieve the coordinated development of economic cooperation and credit cooperation. Yang (2007) points out that farmers' mutual funds cooperatives effectively compensate for the lack of commercial financial institutions and policy financial institutions in rural areas. Xia (2009) believes that the cultivation of rural cooperative financial organization is the most important reform and the most urgent innovation for rural financial system.

\section{Data sources and methods}

\section{Data sources.}

This research combines both first-hand and secondary data to investigate the research problems. One is achieved through the investigation of first-hand data, the investigation questionnaire is divided into three categories, including the questionnaire of mutual fund cooperatives, production cooperatives and farmers who join the mutual funds cooperatives. The secondary data is provided by government. Therefore, the data used in this study has high authenticity and authority, which can provide a reliable basis for the analysis.

There are 578 members in mutual funds cooperatives, all from the production cooperatives, the research object is the 578 members, remove logical contradiction questionnaire, 565 questionnaires were recovered, accounting for $97.75 \%$ of the total members. In this paper, all the data of the canonical correlation analysis were derived from the 565 farmers who join the mutual funds cooperatives and production cooperatives.

\section{Analytical method.}

In this paper, the data from the questionnaires were collected after treatment, firstly, we set the multiple index including production cooperation, supply and marketing cooperation and credit cooperation, and then we use the canonical correlation analysis model, work out the relationship between production cooperation, supply and marketing cooperation and credit cooperation.

\section{Multivariate index and descriptive statistics}

In order to study the relationship between production cooperatives and mutual funds cooperatives in production cooperation, supply and marketing cooperative, credit cooperation, setting up multivariate indexes groups.

\section{Multivariate indexes groups of production cooperation.}

We use five indexes which can represent the objective environment variables to measure the active and passive factors of the members' participation in the production collaboration. First, the "amount of the membership to join the production cooperatives", which can represent the intensity of the subjective intention of the entering production cooperatives, Besides, "years of joining the cooperatives" and "changes in the size of the area" represent the specific indexes that production cooperation can promote production. what's more, the two other indexes are "the output in 2015" 
and "times of attending the exchange meeting". The specific situation and its numerical analysis are in table 4-1.

Table4-1 Multivariate indexes groups of production cooperation

\begin{tabular}{|c|c|c|c|c|c|c|}
\hline Significance & Variable name & Code & Maximum & Minimum & Average & Median \\
\hline $\begin{array}{l}\text { Initial willingness } \\
\text { strength }\end{array}$ & $\begin{array}{l}\text { Amount of the } \\
\text { membership to join } \\
\text { the production } \\
\text { cooperatives }\end{array}$ & joinSpe & 50000 & 0 & 1241.07 & 100 \\
\hline \multirow{2}{*}{$\begin{array}{l}\text { Expaning strength of } \\
\text { production } \\
\text { cooperation }\end{array}$} & $\begin{array}{l}\text { Number of years to } \\
\text { join the cooperatives }\end{array}$ & Years & 6 & 1 & 3.82 & 4 \\
\hline & $\begin{array}{l}\text { Changes in the size of } \\
\text { the area }\end{array}$ & sizeCha & 50 & 0 & 3.82 & 2 \\
\hline $\begin{array}{l}\text { Outputstrength of } \\
\text { production } \\
\text { cooperation }\end{array}$ & $\begin{array}{l}\text { The output of } \\
\text { agriculture products in } \\
\text { 2015(kg) }\end{array}$ & Product & 440000 & 2400 & 65594.9 & 14565 \\
\hline $\begin{array}{l}\text { Insist on the will of } \\
\text { production } \\
\text { cooperation }\end{array}$ & $\begin{array}{l}\text { Times of attending } \\
\text { exchange meeting in } \\
\text { the last six mouths }\end{array}$ & talkhours & 4 & 0 & 2.13 & 2 \\
\hline
\end{tabular}

Data sources: sorted by author

Multivariate indexes groups of credit cooperation.

There are still five indexes of credit cooperation, the specific situation and its numerical analysis, are shown in table 4-2.

Table4-2 Multivariate indexes groups of credit cooperation

\begin{tabular}{|c|c|c|c|c|c|c|}
\hline Significance & Variable name & Code & Maximum & Minimum & Average & Median \\
\hline $\begin{array}{l}\text { Source of joining } \\
\text { credit cooperation }\end{array}$ & $\begin{array}{l}\text { Channel of joining credit } \\
\text { cooperation }\end{array}$ & Channel & 3 & 1 & 1.68 & 2 \\
\hline $\begin{array}{l}\text { Strength of joining } \\
\text { credit cooperation }\end{array}$ & $\begin{array}{l}\text { Amount of the } \\
\text { membership to join the } \\
\text { mutual fund cooperatives }\end{array}$ & Joincash & 10000 & 100 & 851.79 & 100 \\
\hline $\begin{array}{l}\text { Truth degree of } \\
\text { joining credit } \\
\text { cooperation }\end{array}$ & $\begin{array}{l}\text { Application for loans } \\
\text { through mutual funds } \\
\text { cooperatives }\end{array}$ & Loan & 2 & 0 & 1. 3 & 1 \\
\hline \multirow{2}{*}{$\begin{array}{l}\text { Actual demand of } \\
\text { joining credit } \\
\text { cooperation }\end{array}$} & $\begin{array}{l}\text { Times of application for } \\
\text { loans after joining mutual } \\
\text { fund cooperatives }\end{array}$ & Times & 4 & 0 & 1.14 & 1 \\
\hline & $\begin{array}{l}\text { Total application for loans } \\
\text { of Individual }\end{array}$ & Amount & 120000 & 0 & 23392.86 & 10000 \\
\hline
\end{tabular}

Data sources: Sorted by author 


\section{Multivariate indexes groups of supply and marketing cooperation.}

Supply and marketing cooperation includes two parts: supply and sale. So in supply and marketing cooperation respect, in accordance with this logic, we set up multivariate indexes groups of supply and marketing cooperation, including three part, which is "Supply of production materials" 、 "Production service supply" and "Aquatic product sales". the specific situation and its numerical analysis, seeing the table 4-3.

Table4-3 Multivariate indexes groups of supply and marketing cooperation

\begin{tabular}{|c|c|c|c|c|c|c|}
\hline Significance & Variable name & Code & Maximum & Minimum & Average & Median \\
\hline \multirow{3}{*}{$\begin{array}{l}\text { Production } \\
\text { material supply }\end{array}$} & $\begin{array}{l}\text { The proportion of } \\
\text { buying seed through } \\
\text { production } \\
\text { cooperatives }\end{array}$ & infant & 1 & 0 & 0.772 & 0.9 \\
\hline & $\begin{array}{l}\text { The proportion of } \\
\text { buying feed through } \\
\text { production } \\
\text { cooperatives }\end{array}$ & feed & 1 & 0.2 & 0.902 & 1 \\
\hline & $\begin{array}{l}\text { The proportion of } \\
\text { buying drugs through } \\
\text { production } \\
\text { cooperatives }\end{array}$ & drug & 1 & 0 & 0.818 & 1 \\
\hline \multirow[t]{2}{*}{$\begin{array}{l}\text { participation } \\
\text { intensity }\end{array}$} & $\begin{array}{l}\text { The proportion of } \\
\text { buying machinery } \\
\text { through production } \\
\text { cooperatives }\end{array}$ & machine & 1 & 0 & 0.411 & 0 \\
\hline & $\begin{array}{l}\text { The proportion of } \\
\text { buying production } \\
\text { materials through } \\
\text { production } \\
\text { cooperatives }\end{array}$ & buy & 1 & 0.3 & 0.86 & 0.9 \\
\hline $\begin{array}{l}\text { Production } \\
\text { service supply } \\
\text { intensity }\end{array}$ & $\begin{array}{l}\text { Last year whether to } \\
\text { participate in technical } \\
\text { training provided by } \\
\text { production } \\
\text { cooperatives }\end{array}$ & train & 1 & 0 & 0.786 & 1 \\
\hline $\begin{array}{l}\text { Sales service } \\
\text { cooperation } \\
\text { intensity }\end{array}$ & $\begin{array}{l}\text { Total proportion of } \\
\text { agriculture products } \\
\text { sold through } \\
\text { production } \\
\text { cooperatives }\end{array}$ & sell & 1 & 0 & 0.707 & 1 \\
\hline
\end{tabular}

Data sources: Sorted by author 


\section{Empirical research}

\section{Canonical correlation analysis of production cooperation and credit cooperation.}

The only canonical correlation coefficient that has passed the significance test, reaches 0.739. According to the rules of Barlett, using the Wilk test, we found that only the first set of coefficient $\mathrm{P}$ values higher than 95\% confidence level 0.05 threshold, reject the null hypothesis is obviously zero; the remaining four groups of relations are not through the significant test. So we can confirm that the two sets of observed variables have a unique correlation coefficient of 0.739 , showing a high intensity positive correlation, seeing the table 5-1.

Table5-1 Canonical correlation coefficient of production-cooperation and credit cooperation and its significance

\begin{tabular}{cccccc}
\hline No & $\begin{array}{c}\text { Canonical } \\
\text { correlation } \\
\text { coefficient }\end{array}$ & Wilk's & Chi-SQ & DF & Sig. \\
\hline $\mathbf{1}$ & 0.739 & 0.294 & 60.589 & 25.000 & 0.000 \\
$\mathbf{2}$ & 0.490 & 0.649 & 21.410 & 16.000 & 0.163 \\
$\mathbf{3}$ & 0.373 & 0.854 & 7.838 & 9.000 & 0.551 \\
$\mathbf{4}$ & 0.091 & 0.992 & 0.416 & 4.000 & 0.981 \\
$\mathbf{5}$ & 0.003 & 1.000 & 0.001 & 1.000 & 0.982 \\
\hline
\end{tabular}

The extraction of typical variable coefficients of the first group, according to the linear relationship between the standards of the canonical correlation coefficient is 0.739 , we propose the following equation:

$$
\begin{gathered}
V_{S C H Z}=-0.29 \text { years }+0.6 \text { sizeCha }-0.266 \text { product }-0.66 \text { joinSp }+0.343 \text { talkhours } \\
V_{X Y H Z}=-0.064 \text { channel }+0.476 \text { joincash }-0.131 \text { loan }+0.179 \text { times }-0.261 \text { amount }
\end{gathered}
$$

The $V_{S C H Z}$ represents the relationship of production cooperation within the group. Among the variables, the most powerful explanatory variable that the members' participation in the financial investment amount reached -0.66, which may be related to the initial participation in the professional cooperatives. The path of the bureaucratic organization has a significant institutional dependence, it is not strong that the participants' willingness to participate in the initial state. Followed by the average annual agriculture production scale change of 0.6. This shows that participating in production cooperatives can promote members to expand the scale of production. We should notice that there is a positive correlation between the time of participation in the exchange and the intensity of cooperation, the explanatory variable is 0.343 , indicating that the internal communication activities can effectively promote the production of farmer' production cooperation.

$V_{X Y H Z}$ represents credit cooperation. According to the formula, there is a positive correlation between participating in mutual funds cooperatives and entering conditions, the coefficient is 0.476 , the time of borrowing is also positive direction, the coefficient is 0.179 . The situation is different from the production cooperative variable group, the cost of money to join the mutual funds cooperative is a positive impact. The possible reason is that the mutual funds cooperative is an auxiliary service organization which is based on the production cooperation. The amount of loans also shows the scale of anti cooperation tendencies. This is similar to the field of production, which shows that when a member of the farmers change into entrepreneurs, gradually began to reduce dependence on financial cooperatives.

In simple terms, the more the tendency to expand the scale of production, the more possibility to participate in mutual funds business. 


\section{Canonical correlation analysis of supply and marketing cooperation and credit cooperation.}

Canonical correlation analysis was used to obtain five sets of canonical correlation coefficients. It shows that the statistical software provides at least five equations to discuss the relationship. By Wilk significance test, we found that only the first group of 0.692 could reject the original hypothesis is not 0 , the study only retained the first group of canonical correlation coefficient and its relationship equations. The typical correlation coefficient reached 0.692, it shows that the supply and marketing cooperation provided by the production cooperatives is closely related to the credit cooperation provided by the mutual funds. And the positive correlation is consistent with the general theory and practice, seeing the table 5-2.

Table5-2 Canonical correlation coefficient of supply and marketing cooperation and credit cooperation and its significance

\begin{tabular}{lccccc}
\hline & & \multicolumn{3}{c}{ Significance test } \\
\cline { 3 - 4 } No & Canonical correlation coefficient & Wilk's & Chi-SQ & DF \\
\hline $\mathbf{1}$ & 0.692 & 0.310 & 55.580 & 35.000 & 0.015 \\
$\mathbf{2}$ & 0.528 & 0.595 & 24.624 & 24.000 & 0.426 \\
$\mathbf{3}$ & 0.349 & 0.825 & 9.115 & 15.000 & 0.871 \\
$\mathbf{4}$ & 0.206 & 0.940 & 2.945 & 8.000 & 0.938 \\
$\mathbf{5}$ & 0.136 & 0.981 & 0.893 & 3.000 & 0.827 \\
\hline
\end{tabular}

After calculating the typical weight, according to the partial correlation coefficient, construct the significant structural equation group between two groups of typical variables, according to the linear relationship between the standards of the canonical correlation coefficient is 0.692, we propose the following equation:

$$
\begin{gathered}
V_{G X H Z}=-0.429 \text { infant }+0.88 \text { feed }-0.272 \text { drug }+0.178 \text { machine }-1.163 \text { buy }-0.03 \text { train } \\
\quad+0.592 \text { sell } \\
V_{X Y H Z}=-0.569 \text { channel }+0.14 \text { joincash }+0.358 \text { loan }+0.678 \text { times }-0.86 \text { amount } \\
V_{G X H Z} \text { represents the supply and marketing cooperation. Undoubtedly, the biggest contribution }
\end{gathered}
$$
is derived from the proportion of feed purchase parameter 0.88. As the high input of gariculture production, feed determines the absolute value of output at the end of the production cycle. Members will almost always reserve most of the cash used to buy feed. Mutual funds cooperatives provide closed fund lending business to provide cash and convenient procedures for members to buy feed. The partial correlation coefficient of supply and marketing cooperation is 0.592. In addition, seed and drug purchase showed a negative correlation. Where the total purchase ratio is negative for -1.163 , this is mainly due to the result of strong multicollinearity.

The $V_{X Y H Z}$ represents credit cooperation. Mutual funds is a partial correlation characteristic under the influence of supply and marketing cooperation. Under the corresponding effect of supply and marketing cooperation, the contribution of the observation variable "the number of loans" to the typical variables of credit cooperation reached the maximum, 67.8\%. Although the "channel" is negative, due to the valuation rules (because of the minimum value of 1 for cooperatives publicity), showing a positive relationship between supply and marketing cooperation and mutual funds. In addition, the amount of borrowing is also related to the level of mutual funds, indicating that the stronger the mutual fund business, the greater the amount of borrowing.

In simple terms, members who choose to apply for more loans, tend to choose unified purchase of feed and unified sales of agriculture products". 


\section{Canonical correlation analysis of production cooperation and supply and marketing cooperation.}

Canonical correlation analysis was used to obtain five sets of canonical correlation coefficients. Shows that the statistical software provides at least five to discuss a typical relationship. The Wilk significance test showed that only 0.739 of the first group and 0.633 of the second group were able to reject the original hypothesis of no more than 0 , and the study only retained the first group and the second group of canonical correlation coefficient and the equation group. The canonical correlation coefficient reached 0.739 and 0.633 ,that means, the relationship of production cooperation and supply and marketing cooperation are strong. And the positive correlation is consistent with the general theory and practice. Seeing table 5-3.

Table5-3 Canonical correlation coefficient of production cooperation and supply and marketing cooperation and its significance

\begin{tabular}{cccccc}
\hline \multirow{2}{*}{ No } & $\begin{array}{c}\text { Canonical } \\
\text { correlation } \\
\text { coefficient }\end{array}$ & \multicolumn{3}{c}{ significance test } & Sig \\
\cline { 3 - 5 } & Wilk's & Chi-SQ & DF & \\
\hline $\mathbf{1}$ & 0.692 & 0.310 & 55.580 & 35.000 & 0.015 \\
$\mathbf{2}$ & 0.528 & 0.595 & 24.624 & 24.000 & 0.426 \\
$\mathbf{3}$ & 0.349 & 0.825 & 9.115 & 15.000 & 0.871 \\
$\mathbf{4}$ & 0.206 & 0.940 & 2.945 & 8.000 & 0.938 \\
$\mathbf{5}$ & 0.136 & 0.981 & 0.893 & 3.000 & 0.827 \\
\hline
\end{tabular}

After calculating the weight, according to the partial correlation coefficient, construct the significant structural equation group between two groups of typical variables, we propose the following equation:

$$
\begin{gathered}
V_{S C H Z}=-0.671 \text { years }+0.083 \text { sizeCha }+0.747 \text { product }+0.166 \text { joinSp }-0.051 \text { talkhours } \\
V_{G X H Z}=0.091 \text { infant }+0.343 \text { feed }-0.317 \text { drug }+0.852 \text { machine }-0.825 \text { buy }+0.014 \text { train } \\
+0.565 \text { sell }
\end{gathered}
$$

$V_{S C H Z}$ represents the production cooperation relationship within the group. One of the most powerful explanatory variables is the member of the 2015 agriculture output reached 0.747, which shows that the production of cooperation can effectively improve the yield. The "changes in the size of the area " and " amount of the membership to join the production cooperatives " are positively related to the cooperation intensity, which is 0.083 and 0.166 , indicating the scale of agriculture production changes and cash investment amount can effectively promote the production cooperation of farmers.

The $\mathrm{V}_{\mathrm{GXHZ}}$ represents the supply and marketing cooperation. There is no doubt that the biggest contribution comes from the "proportion of buying machinery through production cooperatives", the parameter is 0.852 . Indicating that most of the members will choose to purchase machinery in the production cooperatives. The second is "total proportion of agriculture products sold through aquaculture cooperatives", parameter is 0.565 , that shows members sell agriculture products in a certain extent due to channels provided by production cooperatives. The third is the proportion of feed purchase, the parameter is 0.343 . As the high input of fishery production, feed determines the absolute value of output at the end of the production cycle. In addition, "the proportion of buying seed through production cooperatives" and "Last year whether to participate in technical training provided by production cooperatives" were positively correlated with supply and marketing cooperation, that means buying seed and participating in technical training can effectively save the 
production cost. We should notice that the correlation coefficient of "unified sales ratio" is 0.592. In addition, the purchase of "production material" and "drug" showed a negative correlation, it may because the production cost is not high.

In simple terms, the higher yield members are more likely to choose to purchase equipment in production cooperatives and to sell agriculture products through production cooperatives.

\section{Conclusions and policy recommendations}

\section{Conclusions.}

In this paper, we explained the theory of agricultural production cooperation, supply and marketing cooperation and credit cooperation, and the principle of interaction. Then we use the data from mutual funds cooperatives in Sichuan Province, with the help of Canonical correlation analysis model, testing the impact of production cooperation, supply and marketing cooperation on joining rural mutual fund cooperatives . The conclusions are as follows:

(1) The rural mutual fund cooperatives are produced on the basis of agricultural production cooperation and supply and marketing cooperation, and can promote each other. Combined with the actual research situation, there are many advantages when mutual fund cooperatives are built on the production cooperatives. Therefore, based on farmers' cooperatives, the development of rural mutual fund cooperatives has a positive effect on information asymmetry and transaction cost problem.

(2) Agricultural production has a significant positive impact on farmers' credit cooperation. Farmers have more active participation in the agricultural production, cooperation consciousness and the degree of participation of the cooperatives will be stronger, the more will join the rural financial cooperatives and apply for loans. Among them, the more the tendency to expand the scale of production, farmers will choose to actively participate in mutual fund business.

(3) The degree of production cooperation and supply and marketing cooperation, promote the development of the rural mutual fund cooperatives. These clubs as a farmer's organization carrier of production cooperation, the higher the overall level of cooperation, there are more farmers willing to participate in rural mutual cooperatives, so rural mutual funds have a more extensive mass basis, the probability of the sustainable and healthy development will be greater.

(4) Farmers actively participate in mutual fund cooperatives significantly affect the supply and marketing cooperation. There is a positive correlation between supply and marketing cooperation and credit cooperation. Among them, "Choose more loan application" members were significantly more likely to buy uniform feed and unified sales of agriculture products.

\section{Policy recommendations.}

(1) Expand the scale and scope of cooperation and strengthen the basis for cooperation. In the law and practice, strengthen farmers' understanding of professional cooperatives, guiding professional cooperatives to expend the scope of services, providing a better environment and better service to attract more farmers to join, so as to play a range of economic advantages. Paying attention to training the management ability of cooperatives, promoting the development of the cooperative, and soliding foundation for the rural mutual fund.

(2) Improving the level of farmers' production cooperation and expand the mass basis of rural financial cooperatives. The degree of farmers' cooperation in agricultural production has a significant positive impact on their participation in rural mutual fund cooperatives. Therefore, paying attention to cultivating cooperation consciousness of members, improving the level of agricultural production cooperation, encouraging members to use uniform production standards, promoting members participate in various technology conference, encouraging members to participate in management activities, strengthening members' trust and the sense of belonging professionals cooperatives, laying the foundation for their participation in rural mutual fund cooperatives.

(3) Encourage the high degree cooperation professional cooperatives to take the lead in mutual fund business. The higher the degree of overall cooperation, the more the farmers are willing to participate in the rural mutual fund cooperatives, and then the mutual funds cooperatives have a 
more extensive mass basis, the greater the probability of sustainable and healthy development. Therefore, it is necessary to give more policy support to the professional cooperative, and encourage more qualified professional cooperatives to carry out mutual fund business.

\section{Reference}

[1] Xiaoshan Zhang. Analysis of agricultural production cooperation in developing countries[J]. Rural Economy And society,1988(6):10-17

[2] Jinfu Yu. Stock cooperative farm: the target model of agricultural production organization in contemporary China[J].Economic Review,2014(10):47-50

[3] Jiafu,Lanzhao. Labor scale, organization cost and the evolution of agricultural cooperative organization[J]. Economic Review, 2012(1):32-40

[4] Yangtao,Zhangmeng. Supply and Marketing Cooperative Finance: an innovative model of agricultural supply chain finance in Yunnan[J].China Collective Economy,2013(32):53-56

[5] Juliang Lu. Promoting rural economic cooperation with supply and marketing cooperation: a survey of Fuyang County[J]. Journal of Commercial Economics,1986(14)

[6] Lingyun Ma. The role of supply and marketing cooperatives in rural economic construction[J].China Collective Economy,2011(27):5-6

[7] Liangfang Zheng. Farmers' professional cooperatives and financial support: experience, difficulties and policy suggestions[J].Southwest Financial,2013(4):19-21

[8] Deyuan Zhang,Yajun Zhang. Analysis and Thinking on the mutual fund cooperative organization of farmers[J]. The World of Survey and Research,2007(10):63-64

[9] Pinhas Zusman.The determinants of cost efficiency in cooperative financial institutions: Australian evidence [J].Banking\&Finance, 2001(5):941-964

[10] Berger, Klapper, Udell.The ability of banks to lend to informational opaque small businesses [J].Journal of Banking\&Finance, 2001 (12):2127-2167

[11] Berger, Allen.Udell 1 Small Business Credit Availability and Relationship Lending:The Importance of Bank Organizational Structure [J].Economic, 2002(112):32-531

[12] Masahiko Aoki and Hugh patrick.Clarendon press oxford. The Japanese main bank system [M]. 2002

[13] John Goddarda, Donal McKillopb,John O S Wilsonc.What drives the performance of cooperative financial institutions? Evidence for US credit unions[J].Financial Economics,2008:879-893

[14] Gary Gortona, Frank Schmidb. Corporate governance, ownership dispersion and efficiency: Empirical evidence from Austrian cooperative banking[J].Journal of Corporate Finance,1999:119-140

[15] Wynn Grant, Anne Meanamara. Are China's Finaneial Reforms Leaving the Poor Behind? [D]Paper Presented at the conferenee on Financial Seat or Reform in China, 1996:78-86 